\title{
A Plea for Libya's Gazelles
}

\author{
Mohamed F.A. Essghaier
}

Hunting in modern vehicles has seriously reduced the Libyan gazelle populations. The author, who has been studying them, believes that the future for the three species is gravely threatened unless the Government takes strong measures to enforce the protection laws.

The sharp reduction in the numbers of dorcas and slender-horned gazelles Gazella dorcas and $G$. leptoceros in Libya during the past two decades is mainly the result of overhunting. The wildlife protection law, passed in 1955 and strengthened in 1965, banned all gazelle hunting for six years from 1970, and in 1975 the sale of guns and ammunition was banned temporarily in an effort to halt the slaughter of endangered species. Despite these measures numbers have continued to decrease, especially in the areas of oil exploration and production.

I collected information on gazelle distribution and numbers in northern Libya as part of a study of dorcas gazelle ecology, and also obtained a few records of the endangered slender-horned gazelle. The dama gazelle G. dama is reported to occur in Libya, but $I$ have no recent records. Another bovid on the brink of extinction in Libya is the uddan or Barbary sheep Ammotragus lervia. The one report I received was of a group of nine west of Brega in 1974, of which five were killed later that year.

From December 1974 through December 1976, I travelled to remote locations in northern Libya seeking information on the status of gazelles. In 1974 people living in Gerardia and Nalnut, on the western border, confirmed that the local dorcas gazelle populations had declined, especially those on the Hamada El-Hamra. Gazelles are easily hunted from motor vehicles on this barren plateau, and now only small bands are encountered where once there were herds of a hundred or more in the 1960s.

In January 1975, I saw a herd of 13 dorcas gazelle at Dahra, a concession of the Waha Company, and found their tracks and droppings quite commonly in the wadis and plains of this region. On the same visit, on a flight to Concession 25, I sighted a band of four west of Dahra, and the superintendent of this concession, L.R. Clayton, reported small bands of three to five in the vicinity. I also received a report of two slender-horned gazelles (the white gazelle or 'gazelle abiad') near Dahra where one was shot late in 1974, and I have received two skulls of slender-horned gazelles shot in that locality.

In February 1975, on a visit to Brega and Jebel Zelten, through the cooperation of the Esso Oil Company, I saw only one gazelle, but a herd of about 30 had been seen near Brega shortly before my arrival and I have received reports that several have been killed nearby in recent years. I assume that these were dorcas gazelle, the commonest species in Libya. I was told that large populations occurred at Ejdabia, Gemines and Es-sedra to the north.

In March 1975, with the help of the Occidental Oil Company and the Robert Ray Geophysical Company, I visited El Haruj El Aswad (the Black Hills). Here open plains are broken by escarpments and dry wadis. Tracks and droppings were frequent in the wadis and I periodically encountered groups of 


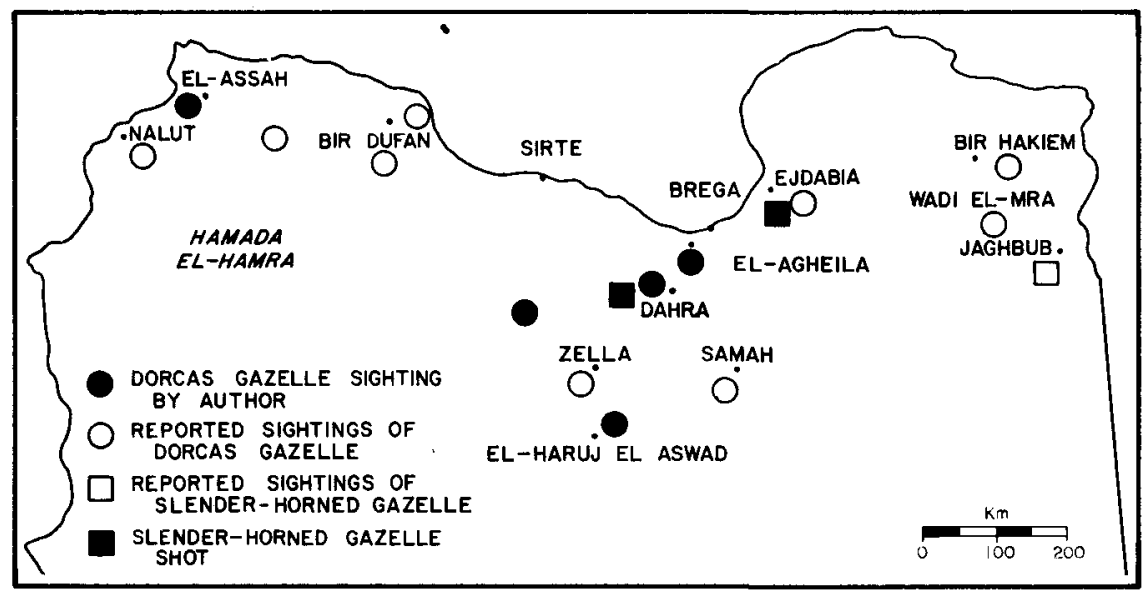

one to three dorcas gazelles in the area. A few months earlier an employee of the Robert Ray Geophysical Company had found a gazelle fawn but failed to rear it. People sometimes remove newborn fawns from their hiding places thinking that they have been abandoned. In late 1974 about 40 gazelles (probably dorcas) were reported near Samah, east of El-Haruj El Aswad, and in February 1975 six were killed near Zella Oasis to the north.

In early April, with several companions, I searched the desert south of Sirte, where the broken ridges that hinder desert travel in this region also provide some refuge places for gazelles. We found small bands of three to eight dorcas gazelles, and recovered the remains of seven that had been recently shot.

In late April 1975, I travelled to the eastern part of Libya in an attempt to confirm the report of a large number of gazelles near Wadi El-Mra, about $200 \mathrm{~km}$ south of Tobruk. The region is laced with land mines left from World War II and one should travel there only with an experienced guide. With the help of the military, I drove about $100 \mathrm{~km}$ into the desert without sighting a single gazelle. Despite the land mines this population is hunted; 34 had been shot by a single hunting party in Wadi El-Mra in August 1974. I also learned that small groups of slender-horned gazelles (10-20 animals) are sometimes seen south of Jaghbub.

I have concentrated my studies on the small population of dorcas gazelle near El 'Assah on the western border of Libya, which I visited monthly from August 1975 through December 1976. The site is accessible to motor vehicles, but the presence of border patrol personnel protected this small population of about 35 animals on the $70-\mathrm{sq}-\mathrm{km}$ study area. Camel and sheep and goat bands use this range, but the shared use seems to have no detrimental effect on the gazelle population.

I feel deep sorrow at the slaughter of these beautiful animals in my native land, and I have grave doubts as to their future unless stern measures are taken to control hunting. Strict enforcement of existing laws would protect these species, and I recommend a ban on all hunting and live capture. I also recommend further study of their distribution, especially that of the slender-horned gazelle in Libya. Furthermore, reserves must be established wherever existing populations have some hope of recovery. Mere delineation of boundaries will be useless without close protection, and this can be done only at considerable cost. Finally, the establishment of captive breeding populations should be investigated. The dorcas gazelle is easy to maintain in captivity - there are several captive herds near Tripoli - and probably the slender-horned and perhaps the dama gazelles could be perpetuated similarly. 